\title{
Neuropsychiatric Symptoms due to Artemisia Absintbium Poisoning
} Pelin Otu Zehirlenmesine Bağlı Nöropsikiyatrik Semptomlar

\author{
Yavuz Altunkaynak ${ }^{1}$, Nurhak Demir ${ }^{2}$, Devrimsel Harika Ertem ${ }^{3}$, Ayten Ceyhan Dirican ${ }^{1}$, Ayhan Köksal ${ }^{1}$ \\ 1Bakırköy Research Hospital for Psychiatric and Neurological Disorders, Clinic of Neurology, Istanbul, Turkey \\ 2Marmara University Pendik Training and Research Hospital, Clinic of Neurology, Istanbul, Turkey \\ 3Ş̧şli Etfal Training and Research Hospital, Clinic of Neurology, Istanbul, Turkey
}

Keywords: Artemisia absinthium, poisoning, cognitive impairment

Anahtar Kelimeler: Artemisia absinthium, zehirlenme, bilişsel bozukluk

\section{Dear Editor,}

Artemisia absinthium (A. absinthium), also known as wormwood, is used as traditional herbal medicine by different societies around its Mediterranean habitat. A. absinthium has traditionally been used for antiparasitic, digestive, and neuropsychiatric effects (1). In spite of its common usage, there are few cases of wormwood intoxications with neuropsychiatric conditions. Here, we report two patients who presented with neuropsychiatric symptoms resulting from wormwood tea consumption.

Case 1: A woman aged 53 years was brought to our emergency department because of an altered state of consciousness. Physical examination upon admission revealed a traumatic swelling at the occipital region with normal vital signs. On neurologic examination, she was disoriented to place and time, and her speech was incoherent without focal neurologic abnormalities. Neuroimaging studies were normal. Laboratory studies revealed the following: urea: $90 \mathrm{mg} / \mathrm{dL}$, creatinine $3.6 \mathrm{mg} / \mathrm{dL}$, creatine kinase: $14.964 \mathrm{U} / \mathrm{L}, \mathrm{Na}: 130 \mathrm{mmol} / \mathrm{L}$, and $\mathrm{K}: 2.3 \mathrm{mmol} / \mathrm{L}$. Intravenous liquid replacement therapy was started for acute renal failure secondary to rhabdomyolysis. Disorientation and communication abnormalities disappeared after two days. She had no history of epilepsy, neuromuscular diseases, kidney disease or alcohol abuse.
She was afebrile during hospitalization. Electromyograpy and electroencephalography (EEG) were normal. She defined the last two days as: "It was like a dream. I was young, as if I was in my twenties. I spent a day in my town where I was born.” Her hallusinogenic experience was questioned for toxic material use or exposure. The patient reported the consumption of wormwood for its anxiolytic effect, which was bought from a herbal market. Due to the limitations of our laboratory, the amount of the dose absorbed by our patient was not evaluated. Rhabdomyolysis-induced acute renal failure secondary to wormwood was considered. She was discharged on the $17^{\text {th }}$ day of her admission.

Case 2: A previously healthy woman aged 32 years presented at the neurology service after three days of fever (self-reported), headache, and amnesia. Physical examination was normal but on neurologic examination, she was disoriented in time and space without focal neurologic abnormalities. Neuroimaging studies were normal. On the day of admission, EEG showed generalized diffuse slow activity. Cerebrospinal fluid analysis had normal pressure and protein, glucose, and electrolyte levels, and leukocyte count. Laboratory studies were in normal ranges. She was afebrile during hospitalization. On the third day of admission, EEG showed normal patterns of brain activity. Similar to the previous patient, she reported the consumption of excessive amounts of

Address for Correspondence/Yazışma Adresi: Devrimsel Harika Ertem MD, Şişli Etfal Training and Research Hospital, Clinic of Neurology, Istanbul, Turkey Phone: +902125436565 E-mail: hkaozhan@gmail.com

Received/Geliş Tarihi: 22.11.2016 Accepted/Kabul Tarihi: 30.01.2017

${ }^{\oplus}$ Copyright 2017 by Turkish Neurological Society

Turkish Journal of Neurology published by Galenos Publishing House. 
wormwood for its anxiolytic effect. She had no further symptoms, and she was discharged on $5^{\text {th }}$ day of admission.

It is believed that herbal medicine is natural and without harm. In general, it is easy to maintain herbal drugs. They are sold as teas, extracts, and fresh or dried plants. However, it is not clear as to which doses effect medical or toxic doses because herbal medicines generally do not undergo the same testing as pharmaceuticals. A. absinthium was used historically as a traditional herbal medicine for several purposes such as digestive, antiparasitic, and anxiolytic effects. Although widely used, there is no standard dose for wormwood (1). The wormwood plant is used as the main component of the spirit drink Absinthe. Padosch et al. (2) claimed that chronic use of Absinthe might cause a syndrome called absinthism, which is characterized by hyperexcitability, seizures, and hallucination. Magnan (3) reported that visual and auditory hallucinations accompanied by alterations in consciousness after the consumption of Absinthe might be seen in absinthism. Despite these, Bora and Sharma (4) investigated the protective effects of $A$. absinthium on cerebral oxidative stress and behavioral disturbances induced by cerebral ischemia in rats. Methanol extracts of wormwood significantly reduced memory loss and motor deficits. The authors suggested that A. absinthium was neuroprotective and might be useful in the treatment of stroke (4). This may be the neurotoxic and neuroprotective feature of this plant. Our first patient had cognitive disturbances and psychiatric symptoms as hallucination for nearly 48 hours. Our second patient had impaired cognition for 5 days. Unfortunately, we were not able to assess the amount of the dose absorbed by our patients.

Wormwood is approved by the German Commission E for the treatment of patients with dyspepsia, loss of appetite, and biliary dyskinesia (5). Wormwood is commonly used in tea, powder, and capsule forms. In our country, in general practice, one or two teaspoonfuls of dry leaves of A. absintbium boiled in water is used for its digestive and anxiolytic effects. We believe that our patients had wormwood extract at high doses due to the signs of poisoning.
There is an increasing demand for complementary and alternative medicine. Uncontrolled marketing of herbs and products derived from them is a major health problem that should be taken seriously. These cases demonstrate the dark side of herbals with their toxic potential. A. absintbium can have opposing effects at different doses.

Ethics

Informed Consent: Consent form was filled out by all participants.

Peer-review: Internally peer-reviewed.

Authorship Contributions

Surgical and Medical Practices: Y.A., N.D., Concept: D.H.E., A.K., Design: Y.A., D.H.E., Data Collection or Processing: N.D., A.C.D., Analysis or Interpretation: D.H.E., A.C.D., A.K., Literature Search: D.H.E., Writing: Y.A., D.H.E.

Conflict of Interest: No conflict of interest was declared by the authors.

Financial Disclosure: The authors declared that this study received no financial support.

\section{References}

1. Yarnell EL, Abascal K. Artemisia absinthium (Wormwood). In: Pizzorno JE, Murray MT, editors. Textbook of Natural Medicine 4th ed. USA: Elsevier Press; 2013. p. 591-593.

2. Padosch SA, Lachenmeier DW, Kröner LU. Absinthism: a fictitious 19th century syndrome with present impact. Subst Abuse Treat Prev Policy 2006;1:14

3. Magnan V. On the comparative action of alcohol and absinthe. The Lancet 1874;104:410-412.

4. Bora KS, Sharma A. Neuroprotective effect of Artemisia absinthium L. on focal ischemia and reperfusion-induced cerebral injury. J Ethnopharmacol 2010;129:403-409.

5. Blumenthal M, Busse WR, Goldberg A. The complete German Commission E monographs: therapeutic guide to herbal medicines. Austin, TX: American Botanical Council; 1998:232-233. 